\title{
Revisiting the Problem of Post-Soviet Revolutions: The Armenian Revolution Makes Some Difference
}

\author{
Pavel K. Baev \\ Peace Research Institute Oslo (PRIO), Oslo, Norway
}

\begin{abstract}
The phenomenon of recurrent revolution in the post-Soviet political space deserves a new examination, as the Year 2019 marks not only 30 years since the chain of revolutions in Eastern Europe, but also the first anniversary of the revolution in Armenia. There are scant reasons to expect that economic underperformance or even a sharp spasm of crisis would bring any of the seven unmistakably authoritarian post-Soviet regimes to an abrupt end, but the deepening resentment against corruption could produce a powerful demand for change in the course of elections, which theses regimes feel obliged to stage. Manipulations of elections are the most common trigger for revolutions, but the big question of whether such explosions of social energy could deliver on the demand for change is set to remain open.
\end{abstract}

Keywords: revolution, protest, post-Soviet, Armenia

\section{Introduction}

The phenomenon of modern revolutions invites a re-evaluation in Year 2019, when researchers reflect on the 40th anniversary of the collapse of the Shah regime in Iran and on the 30th anniversary of the spectacular sequence of anti-Communist revolutions in Eastern Europe (Brookings Institution, 2019). ${ }^{1}$ Every historical revisit inevitably brings parallels with the recent overthrow of the Omar al-Bashir's regime in Sudan, forced departure of President Abdelaziz Bouteflika in Algeria, and the still on-going uprising against the Nicolas Maduro junta in Venezuela. This analysis will leave these contemporary crises aside in order to focus on the revolutionary developments in the former Soviet space, aiming to add new data to the previous examination (Baev, 2011). ${ }^{2}$ Of particular interest are the processes in the Caucasus, which saw an explosion of violent conflicts and coups in the early 1990s, as well as the "Rose revolution" in Georgia in 2003, but remained remarkably serene for most of this decade (Iskandaryan, 2011). ${ }^{3}$ The Russo-Georgian war of August 2008, while not of revolutionary character, apparently produced such a heavy impact that neither the sudden arrival of the "Arab Spring" in 2011, nor the rise of ISIS (Daesh) in 2014 re-ignited any instability in the South Caucasus or, for that matter, in the Russian North Caucasus. What has altered this tranquil picture was the successful uprising in Armenia in April-May 2018, which gained the somewhat misleading name of "Velvet revolution"

Pavel K. Baev, Dr., research professor at the Peace Research Institute Oslo (PRIO), Oslo, Norway; senior non-resident scholar at the Brookings Institution, Washington DC, USA; senior associate research fellow at the Institut Francais des Relations Internationales (IFRI), Paris, France.

1 The Brookings Institution produced a rich collection of essays on the Islamic revolution in Iran, see "Iran's Revolution..." (2019).

${ }^{2}$ My earlier examination of this political phenomenon is in Baev (2011).

${ }^{3}$ One insightful and foresight-full analysis of the revolutionary dynamics in the Caucasus is Iskandaryan (2011). 
(the reference to Czechoslovakia is not very accurate and serves perhaps only to avoid any association with notorious "color revolutions"). This peaceful removal of old elites from power is still very much in the making, but it definitely provides a useful point of departure for a fresh look at the dynamics of always unpredictable revolutions.

\section{Typical Features and Uncertain Propositions}

The data on post-Soviet revolutions are fragmented and open to interpretation, but it can be confidently asserted that the N-parameter is actually not as low as commonly perceived. Every count is inevitably subjective, and it is certainly erroneous to see every mass protest as an attempted revolution. In this regard, the sequence of street rallies and "Occupy" activities in Moscow from December 2011 to January 2013 cannot qualify as a failed revolution, even if these events produced a new strong counter-revolutionary drive in the Kremlin (Gelman, 2013). The key distinction here is the intent to overthrow the government and to capture political power, and the vast majority of Moscow protesters had no illusions regarding the feasibility of such outcome. There are always border-line cases, where small-scale protests might trigger a crisis of governance, and the unrest in Abkhazia (oscillating as the moment of this writing) could provide an example (Korostikov, 2019). ${ }^{4}$ This case invites a clarification that quasi-independent states, like Abkhazia, are legitimate items for the data on the post-Soviet revolutions, which implies no inference for the issue of legitimacy of their existence.

A few more considerations can be advanced before the data list is compiled - and a reasonably precise definition extracted from its examination. Mass protests and violent clashes in particular regions, not aimed at or leading to capture of power in a national capital, have to be excluded as peripheral to the phenomenon in question. The uprising in Andijan, Uzbekistan in May 2005 and the worker's revolt in Zhanaozen, Kazakhstan in December 2011 are thus eliminated, and while the violent turmoil in Bishkek, Kyrgyzstan in April 2010 easily qualifies as a revolution, the follow-up revolts in the Osh province are bracketed out. The most interesting border-case is the struggle for power in Adjara in May 2004, which has many features of a revolution, but still has to be left out because this Georgian region did not attempt a secession and so was not even a quasi-independent unit (ICG, 2004). Events outside the borders of the former Soviet Union fall beyond the scope of this analysis, so the July 2008 riots in Ulaanbaatar, Mongolia are excluded. The three Baltic states-Estonia, Latvia, and Lithuania - have successfully escaped from the post-Soviet space and belong now to Europe shaped by the norms of the EU, so they are also excluded, with the note that the only major disturbance - the "Bronze soldier" riots in Tallinn, Estonia in April 2007-cannot possibly qualify as an attempted revolution (Tapon, 2018). Finally, the time-scale is set from 2000, which is certainly arbitrary, but the turmoil and coups of the 1990s belong to another era.

\footnotetext{
${ }^{4}$ On the on-going unrest accompanying the presidential elections in Abkazia, see Korostikov (2019).
} 
Table 1

The List of Post-Soviet Revolutions

\begin{tabular}{llllll}
\hline State & Date & Success & Violence & Elections & Russia/West \\
\hline Azerbaijan & 2003 & No & Government & Yes & Yes/Yes \\
Georgia & 2003 & Yes & Opposition & Yes & No/Yes \\
Abkhazia & 2004 & Yes & Opposition & Yes & No/No \\
Ukraine & 2004 & Yes & None & Yes & Yes/Yes \\
Kyrgyzstan & 2005 & Yes & Both & Yes & No/Yes \\
Azerbaijan & 2005 & No & Government & Yes & Yes/No \\
Belarus & 2006 & No & Government & Yes & Yes/Yes \\
Georgia & 2007 & No & Government & No & Yes/No \\
Armenia & 2008 & No & Government & Yes & No/No \\
Georgia & 2009 & No & None & No & No/Yes \\
Moldova & 2009 & Yes & Opposition & Yes & No/No \\
Kyrgyzstan & 2010 & Yes & Both & Yes & Yes/Yes \\
Belarus & 2010 & No & Government & Yes & Yes/No \\
Armenia & 2013 & No & None & No & No/No \\
Abkhazia & 2014 & Yes & Opposition & No & No/No \\
Ukraine & $2014-2015$ & Yes & Government & None & Yes \\
Armenia & 2018 & Yes & &
\end{tabular}

These limitations leave the list of 17 cases, as presented in Table 1, which is certainly very "unscientific" but still allows for an attempt to identify typical features of this set of revolutions and to formulate a few propositions. The first three columns are self-explanatory; the fourth one shows whether government resorted to suppression, or the opposition to forceful measures, or both. The fifth column indicates whether elections provided a cause for the revolutionary mobilization, and the sixth one shows whether Russia provided support for the regime, or the West supported the uprising, or both.

One immediate observation from this open collection is that the frequency of revolutions has significantly decreased after 2010, while the success rate has recently improved. Another observation is that the involvement of Russia and the West tends to be symmetric, so that even a symbolic support from the latter prompts a strong counter-revolutionary reaction from the former. The third observation is that the revolutionary activities are disproportionally concentrated in the Caucasus, which saw 10 attempts at overthrowing the government, of which four were successful. Russia during Vladimir Putin's "era" has remained revolution-free, and the authoritarian regimes in Central Asia have been safe from this threat, with the obvious exception of semi-democratic and revolution-prone Kyrgyzstan. The final observation is that entirely non-violent events are relatively rare, and while the failure of revolutionary attempts is typically determined by the government's suppression, the success is often decided by the readiness of street crowds to forcefully storm some key seats of power.

These observable features of nine successful and eight unsuccessful revolutions make it possible-after somewhat more thorough examination of this set of cases - to advance four challenging and some would argue, dubious propositions. The first one is that the so-called "demonstration effect", or what Henry Hale called "regime change cascade", is no longer working, perhaps temporarily (Hale, 2013). The social mechanism behind this "chain reaction" cannot be researched and described with scientific precision, but it was easily visible in the sequence of anti-Communist revolutions in Eastern Europe in 1989 and in the fast spread of 
turmoil across the wider Middle East in 2011. It is possible to find connections between the "Rose revolution" in Georgia in 2003, "Orange revolution" in Ukraine in 2004, and "Tulip revolution" in Kyrgyzstan in 2005, and perhaps some other events of that tumultuous period, but presently - despite the instant spread of news - such connections do not function. The spectacular "Euro-Maidan" in Kiev, with its protracted drama and shocking victory in February 2014, produced great international resonance, but hardly any regime-destabilizing impact across the former Soviet space. This may be counter-intuitive given the spread of social networks and cross-border ties, but even the despotic regime in Uzbekistan managed to pass through the natural transition caused by death of Islam Karimov in September 2016 without any turmoil.

The second proposition is that the economic factors, and in particular the sharp spasms of recessions, have no influence on, or at least no correlation with the intensity and frequency of revolutions. This argument goes strictly against the Leninist theory of revolutions and Marxist doctrine on the primacy of economic over politics, in which the cohort of political leaders in their 1960s and 1970s (prevalent in Russia, Belarus, and Central Asia) are thoroughly schooled, whatever their current persuasions. It is, nevertheless, plain obvious that neither the severe but short economic crisis of 2008-2009, nor the more protracted recession of 2014-2016, originating primarily in Russia, had any discernible impact on the social propensity to revolt against the ruling regimes. Russian experts are trying to find a logical connection between the contraction of disposable incomes, lasting for more than five years, and the accumulation of discontent, but the local protests, for instance in Arkhangelsk and Yekaterinburg, can hardly be interpreted as symptoms of a brewing revolutionary situation (Pertsev, 2019).

The third proposition is about the evolving agenda of revolutions: It is apparently shifting from demands for democratic reforms and greater ties with (or orientation toward) Europe, or the West more generally, to more mundane demands for removal of corrupt elites, which are rooted in the more abstract desire for greater social justice (Minchenko Consulting, 2018). ${ }^{5}$ This shift is certainly far less measurable than the correlation, or the lack of thereof, between the economic spasms and revolutionary events; still, it is possible to make this argument reflecting on the desperate effort of the activists leading the angry crowd in Chisinau, Moldova to plant the EU flag on the parliament building during the April 2009 riot - and the lack of any signs of this flag in the revolutionary events since then. Quite possibly, the internal problems in the EU, culminating in the "Leave" majority vote in the 2016 referendum in the UK (yet to be implemented as of this writing), contributed strongly to the sober acknowledgement by the opinion-makers in many revolutionary situations that the option of joining the EU is neither feasible nor even desirable. What is typically hidden by the anti-corruption focus of the new anger is the underlying trend of increasing the political distance from Russia, which is stuck in the profoundly corrupt policy-making, and moving closer to the European political ideal of openness and accountability in politics.

The fourth proposition suggests that the success of a revolutionary attempt does not depend upon a strong personal leadership in the opposition, which also does not determine the ability of the revolution to make a difference. Revolutions in Georgia (2003), Ukraine (2004), and Kyrgyzstan (2005) are strikingly different in this regard: The first one had a strong leader and made a difference; the second one had two strong leaders and did not make a difference (as confirmed by the election of Victor Yanukovych as president in 2010); and the third one was essentially leader-less and useless. This argument not only goes against the Leninist theory of revolution, in which a determined leadership is a key element, but also challenges the common political sense,

\footnotetext{
${ }^{5}$ Interesting research on this shift can be found in the Mincheko Consulting report (2018).
} 
which suggests that the presence of an alternative elite grouping able to take control after the typically sudden victory is an important condition for executing the agenda of a revolution. The triumph of "Euro-Maidan" in February 2014 confirms the first part of the proposition in question, because the course of this revolution was severely distorted by the Russian aggression.

The "Velvet revolution" in Armenia in spring 2018 provides a useful case for testing these propositions, which by their very nature cannot be decisively proven, even with the possible increase of the data base in the near future.

\section{Taking Stock of the Armenian Revolution}

The latest entry in the list may be entirely sui generis, and the protagonists take pains to explain that it is different from "color revolutions" (obviously trying to mollify Russia), but its key features are absolutely relevant for this examination (Iskandaryan, 2018; Derluguian \& Hovhannisyan, 2018). ${ }^{6}$ The desperate demand for change in the large part of the electorate, which did not manifest itself in the elections, was a shocking surprise for the authorities (as well as for Russia), besides giving new hope to the advocates of non-violent revolutions (Baev, 2018). The removal from the positions of power of the well-entrenched political elite continues as of the mid-2019, but some provisional assessments can be made (Markedonov, 2019). ${ }^{7}$

The proposition about the disappearance of the "demonstration effect" fits quite well with the Armenian case: There is clearly no connection between this uprising and the Ukrainian "Euro-Maidan" four years previously, and there is no discernible resonance from the revolutionary victory in Yerevan across the post-Soviet political space. Chronologically, it is possible to place this revolution in the row with the mass uprisings in Algeria, Sudan, and Venezuela, but in neither of these countries was there any informed attention to, or interest in the events in the small Caucasian state. Even for the protesters in various Russian regions, the Armenian example does not provide any noticeable inspiration, which is somewhat surprising given the rather detailed and generally neutral coverage of the revolution by the mainstream Russian media, not to mention the social networks.

The proposition about weak economic causation also finds strong support: Armenian economy has been struggling for a long time, and the recession in Russia in 2014-2016 did plenty of damage, but the situation was improving in 2017-2018, so no specific economic driver or trigger for the revolution can be found. It is easy to see economic causes behind the wave of street protests in summer 2015, focused on the rise of electricity rates by $17 \%$, so that the unrest was labelled the "Electric Yerevan" (Derluguian \& Andreasyan, 2015). ${ }^{8}$ The government made no attempt to suppress the protests, which might have produced the perception that it was reasonably safe to partake in collective actions, but the memories of violent clashes on 1-2 March 2008 still remained fresh. The return of thousands of labor migrants from Russia, where the demand for cheap labor in the crisis-affected construction sector contracted, may have increased the numbers of potential protesters, but that is at best an implicit impact of economic factors.

The proposition about the evolving agenda of revolutions is quite well illustrated by the Armenian case: The demand for more democracy was narrowed down on the removal from power of a corrupt elite grouping,

\footnotetext{
${ }^{6}$ See, for instance the interview of Alexander Iskandaryan (2018) with a conservative media. A thorough examination of the unique features of the Armenian case is Derluguian and Hovhannisyan (2018).

${ }^{7}$ On the elite reshuffling, see Markedonov (2019).

${ }^{8}$ Good analysis of that round of protests can be found in Derluguian and Andreasyan (2015).
} 
while the causes of liberties and human rights were significantly downplayed. The most interesting feature was the deliberate emphasis in the protest movement on preserving the alliance with Russia and refraining from any rapprochement with the West, which in fact amounted to a significant change from the previous stance of its leaders (Abrahamyan, 2019). This insistence on preserving the foreign policy guidelines was perhaps necessary for ensuring Russia's neutral stance regarding the generally undesirable revolution, but it also reflected the realistic assessment in broad strata of Armenian society (as well as in other post-Soviet states) of limited and further diminishing capacity of the EU and NATO to engage with pro-Western aspirations and to deliver meaningful support for democratic reforms.

Finally, the proposition on the low importance of leadership finds no support whatsoever. The "Velvet revolution" was to such a degree driven by the determination and decisions of a single person that it could be described as a one-man show. Strange thing is that Nikol Pashinyan was not a new-comer to the political arena, and in his previous activities he did not show any of the charisma that came out so strong in the crucial standoff and carried him through the follow-up maneuvering and elections (Roth, 2018). ${ }^{9}$ He carefully avoids any significant turns in charting Armenia's foreign policy course but tries to make a big difference in how the country is governed by executing a thorough replacement of the deeply entrenched old elite despite the obvious lack of experience and competence in the new generation of protesters-turning-bureaucrats (Khalatyan \& Krivosheev, 2018). His efforts at exterminating corruption resemble the policies of Mikhail Saakashvili in 2004-2005, who was indeed able to achieve significant success in reforming Georgian governance, but they also make him a seriously alien and unreliable counter-part for the Kremlin.

\section{Conclusions}

Armenia has a track record as the country most prone to revolutions and coups in the last 20 years across the post-Soviet area, but it is increasingly doubtful whether it is useful and even correct to outline this political space. The political distance from Moldova to Turkmenistan has indeed increased greatly, and even if the Lukashenko regime in Belarus remains as authoritarian as Aliyev regime in Azerbaijan, its future will be determined by the pull of Central European ties, which are mon-existent in the Caucasus and Central Asia. A hypothetic revolution in the latter region might have more in common with the uprisings in Tunisia or Algeria than with the peaceful overthrow of corrupt regime in Armenia. The Armenian case only serves as a reminder that authoritarian regimes tend to appear far more solid than they really are.

There are scant reasons to expect that economic underperformance or even a sharp spasm of crisis would bring any of the seven unmistakably authoritarian post-Soviet regimes to an abrupt end, but the deepening resentment against corruption could produce a powerful demand for change in the course of elections, which theses regimes feel obliged to stage. Manipulations of elections are the most common trigger for revolutions, but the big question of whether such explosions of social energy could deliver on the demand for change is set to remain open. In the Armenian case, it has a distinct international projection: Pashinyan's team struggles to prove that the spectacular revolution of their making has made a difference, and the Kremlin is firm set to establish that it did not. There are indeed many good reasons to expect that the access to power would produce the usual corrupting effect on the new leaders, and the Russian leadership is not only cherishing such expectations but working on them. Armenia has, nevertheless, a good chance to make a new start with reforms,

\footnotetext{
9 An insightful portrait is presented by Roth (2018).
} 
but it cannot hope that Moscow would remain indifferent to this progress. Geopolitics is, after all, just a game to play for Putin and his courtiers, but revolution is an existential threat that will sooner or later strike with irresistible force.

\section{References}

Abrahamyan, E. (21 March 2019). Pashinyan's unclear vision for Armenian foreign policy. Eurasia Daily Monitor. Retrieved from https://jamestown.org/program/pashinyans-unclear-vision-for-armenian-foreign-policy/

Baev, P. K. (2011). A matrix for post-Soviet "color revolutions": Exorcising the devil from details. International Area Studies Review, 14(2), 3-22.

Baev, P. K. (23 July 2018). What made Russia indifferent to the revolution in Armenia. Caucasus Analytical Digest, (104), $20-24$.

Brookings Institution. (2019). Iran's revolution, 40 years on-what it has meant for Iran, America, and the region. Retrieved from https://www.brookings.edu/series/irans-revolution-forty-years-on/

Derluguian, G., \& Andreasyan, Z. (September/October 2015). Armenia's fuel protests. New Left Review, (95), 29-48.

Derluguian, G., \& Hovhannisyan, R. (2018). The Armenian anomaly: Toward an interdisciplinary interpretation. Demokratizatsiya, 26(4), 441-464.

Gelman, V. (2013). Cracks in the wall: Challenges to electoral authoritarianism in Russia. Problems of Post-Communism, 60(2), 3-10.

Hale, H. (May 2013). Regime change cascades: What we have learned from the 1848 revolutions to the 2011 Arab spring. Annual Review of Political Science, 16, 331-353. Retrieved from https://www.annualreviews.org/doi/abs/10.1146/annurev-polisci-032211-212204

ICG Europe Briefing. (18 August 2004). Saakashvili's Ajara success: Repeatable elsewhere in Georgia? Brussels. Retrieved from https://d2071andvip0wj.cloudfront.net/saakashvili-s-ajara-success-repeatable-elsewhere-in-georgia.pdf

Iskandaryan, A. (2011). Revolutionary ideals: Political discourses in the South Caucasus. In A. Iskandaryan (Ed.), Identities, ideologies and institutions: A decade of insight into the Caucasus (pp. 89-97). Yerevan: Caucasus Institute.

Iskandaryan, A. (14 February 2019). The revolution in Armenia was not colored but velvet. Interview with Pravda.ru (in Russian). Retrieved from https://www.pravda.ru/world/1406936-iskandarjan/

Khalatyan, H., \& Krivosheev, K. (12 December 2018). Old Armenia meets "Armenia of the future": The old ruling elite under Pashinyan. Commentary. Carnegie Moscow Center. Retrieved from https://carnegie.ru/commentary/77995

Korostikov, M. (22 May 2019). Apsny has woken up out of season. Kommersant (in Russian). Retrieved from https://www.kommersant.ru/doc/3976031

Markedonov, S. (28 May 2019). Armenia: No end to the revolution? Analytics \& Comments (in Russian). Russian International Affairs Council. Retrieved from https://russiancouncil.ru/analytics-and-comments/analytics/armeniya-net-urevolyutsii-kontsa/

Minchenko Consulting. (October 2018). New political reality and the risk of anti-elite wave in Russia. Retrieved from http://www.minchenko.ru/analitika/analitika_77.html

Pertsev, A. (21 May 2019). Radicalization and symbolism: New face of Russian protest. Commentary (in Russian). Carnegie Moscow Center. Retrieved from https://carnegie.ru/commentary/79155

Roth, A. (8 May 2018). He is not a populist, he is popular: Nikol Pashinyan becomes Armenian PM. The Guardian. Retrieved from https://www.theguardian.com/world/2018/may/08/hes-not-a-populist-hes-popular-nikol-pashinyan-becomes-armenian-pm

Tapon, F. (7 July 2018). The Bronze Soldier explains why Estonia prepares for a Russian cyberattack. Forbes. Retrieved from https://www.forbes.com/sites/francistapon/2018/07/07/the-bronze-soldier-statue-in-tallinn-estonia-give-baltic-headaches/ 